\title{
PENGARUH PEMBERIAN FISIOTERAPI DADA TERHADAP KEBERSIHAN JALAN NAPAS PADA PASIEN ISPA DI DESA PUCUNG EROMOKO WONOGIRI
}

\author{
Oleh : \\ Dinar Ariasti ${ }^{1}$,Sri Aminingsih ${ }^{2}$,Endrawati ${ }^{3}$
}

\begin{abstract}
Background: In the Indonesian case ARI (Acute Respiratory Infection) ranks first in the number of outpatients most. This shows morbidity due to ARI is still high. The government has planned to bring it down to 3 per 1,000 infants in 2010 , however, the morbidity can be down depend on the number of risk factors, particularly those associated with the standard strategy of case management, immunizations, and risk factor modification. One of the management for the cleanliness of the airway in patients with ARI is chest physiotherapy.

The purpose of this study was to determine the effect of chest physiotherapy on the cleanliness of the airway in patients with ARI in the Pucung village, Eromoko, Wonogiri.

The subjects of this study were children Pucung villagers, Eromoko, Wonogiri aged under 10 years who suffered from ARI, amounting to 26 respondents. Sampling is done by accidental sampling technique is limited because the number of respondents.

Data collected by observation using a pretest before giving chest physiotherapy and posttest after giving chest physiotherapy.

The results of the pretest before giving chest physiotherapy is the number of respondents who clean airway hygiene there are 3 respondents $(11.53 \%)$ and the number of respondents who did not clean her airway hygiene, there are 23 respondents (88, 47\%). Posttest results after administration of chest physiotherapy is the number of respondents who clean airway hygiene, there are 18 respondents $(69.23 \%)$ and the number of respondents who did not clean her airway hygiene there are 8 respondents $(30.70 \%)$. Then the gathered data was analyzed by Paired t-test with $p=5 \%(0: 05)$, so that the obtained $p=0.000 P$ $<0.05$. Based on the research results of Ho rejected and Ha accepted.
\end{abstract}

The conclusion of this study is that there is the effect of chest physiotherapy on the cleanliness of the airway in patients with ARI.

Keywords: Chest Physiotherapy, Health Airway, Acute Respiratory Infection

\section{PENDAHULUAN}

Infeksi saluran pernapasan akut (ISPA) merupakan salah satu penyebab kematian tersering pada anak di negara sedang berkembang. Infeksi saluran pernapasan akut ini menyebabkan empat dari 15 juta perkiraan kematian pada anak berusia di bawah 5 tahun pada setiap tahunnya. (Widjaja, 2003)

Infeksi saluran pernapasan akut merupakan penyebab terpenting morbiditas dan mortalitas pada anak. Sebagian besar ISPA terbatas pada ISPA atas saja, tetapi sekitar $5 \%$ nya melibatkan laring dan respiratori bawah berikutnya, sehingga 
berpotensi menjadi serius. (Rahajoe, 2008)

Sejak tahun 1994 WHO telah menerapkan program pemberantasan ISPA, khususnya pneumonia. Pada tahun 1990, Konferensi Tingkat Tinggi (KTT) Anak di New York telah membuat kesepakatan untuk menurunkan kematian akibat ISPA sebesar $30 \%$ pada tahun 2000. Implementasi strategi pemberantasan ISPA telah dilakukan oleh banyak negara termasuk Indonesia, tetapi hasil yang dicapai bervariasi. (Rahajoe, 2008)

Di Indonesia kasus ISPA menempati urutan pertama dalam jumlah pasien rawat jalan terbanyak. Hal ini menunjukkan angka kesakitan akibat ISPA masih tinggi. Pemerintah telah merencanakan untuk menurunkannya hingga 3 per 1000 balita pada tahun 2010. Akan tetapi, keberhasilannya bergantung pada banyaknya faktor resiko, terutama yang berhubungan dengan strategi baku penatalaksanaan kasus, imunisasi, dan modifikasi faktor resiko. (Rahajoe, 2008)

Fisioterapi dada merupakan kelompok terapi yang digunakan dengan kombinasi untuk memobilisasi sekresi pulmonar. Terapi ini terdiri dari drainage postural, perkusi dada, dan vibrasi. Fisioterapi dada harus diikuti dengan batuk produktif dan pengisapan pada klien yang mengalami penurunan untuk batuk. (Potter dan Perry, 2006) Menurut Muttaqin (2008), tujuan fisioterapi dada adalah membuang sekresi bronkial, memperbaiki ventilasi, dan meningkatkan efisiensi otot-otot pernapasan.

Desa pucung adalah salah satu desa yang berada di kecamatan Eromoko kabupaten Wonogiri. Hasil survey awal diperoleh data anakanak balita cenderung lebih banyak mengalami ISPA dibanding dengan dewasa. Dari wawancara dengan beberapa orang tua anak yang mengalami ISPA, penatalaksanaan yang dilakukan selama ini adalah hanya dengan memberi obat yang dibeli di apotek atau obat yang telah diresepkan dokter. Mereka belum mengetahui tentang fisioterapi dada dan manfaatnya.

Dari fenomena di atas, maka peneliti memandang perlu untuk melakukan penelitian tentang "Pengaruh Pemberian Fisioterapi Dada terhadap Kebersihan Jalan Nafas pada Pasien ISPA di Desa Pucung Eromoko Wonogiri".

Rumusan Masalah

Berdasarkan uraian dalam latar belakang masalah di atas maka rumusan masalah pada penelitian ini adalah "Apakah ada pengaruh pemberian fisioterapi dada terhadap kebersihan jalan nafas pada pasien ISPA di Desa Pucung Eromoko Wonogiri ?"

Tujuan Penelitian

Untuk mengetahui kebersihan jalan nafas sebelum dan sesudah dilakukan fisioterapi dada pada pasien ISPA di Desa Pucung Eromoko Wonogiri.

\section{METODE PENELITIAN}

Penelitian ini merupakan penelitian eksperimen semu atau quasi eksperimen dengan rancangan pre post eksperimental untuk mengetahui pengaruh pemberian fisioterapi dada terhadap kebersihan jalan napas pada pasien ISPA, dengan cara membandingkan kebersihan jalan napas sebelum dan sesudah diberi tindakan fisioterapi dada. (Suyanto, 2011)

Populasi merupakan seluruh subjek atau objek dengan karakteristik 
tertentu yang akan diteliti. Bukan hanya objek atau subjek yang dipelajari saja tetapi seluruh karakteristik atau sifat yang dimiliki subjek atau objek tertentu. (Hidayat, 2008) Populasi yang digunakan dalam penelitian ini adalah seluruh anak-anak berusia dibawah 10 tahun di Desa Pucung, Eromoko, Wonogiri yaitu sebanyak 150 orang.

Menurut Hidayat (2008), sampel merupakan bagian populasi yang akan diteliti atau sebagian jumlah dari karakteristik yang dimiliki oleh populasi. Sampel pada penelitian ini adalah semua anak-anak yang ditemukan menderita ISPA di Desa Pucung, Eromoko, Wonogiri.

Teknik sampling merupakan suatu proses seleksi sampel yang digunakan dalam penelitian dari populasi yang ada, sehingga jumlah sampel akan mewakili keseluruhan populasi yang ada, secara umum ada dua jenis pengambilan sampel, yakni probability sampling dan non probality sampling. (Hidayat, 2008)

Sedangkan teknik sampling yang diambil pada penelitian ini adalah teknik sampling aksidental, yaitu cara pengambilan jenuh jika jumlah populasinya sedikit, seperti bila sampelnya kurang dari tiga puluh maka anggota populasi tersebut diambil seluruhnya untuk dijadikan sampel penelitian. (Hidayat, 2008)

Alat Penelitian / Instrumen Penelitian Pada penelitian ini menggunakan stetoskop dan lembar observasi tentang kebersihan jalan napas untuk memeriksa kebersihan jalan napas pada pasien ISPA sebelum dan sesudah fisioterapi dada.

Pengumpulan data merupakan kegiatan penelitian untuk mengumpulkan data. Sebelum melakukan pengumpulan data, perlu dilihat alat ukur pengumpulan data agar dapat memperkuat hasil penelitian. Alat ukur pengumpulan data tersebut antara lain dapat berupa kuesioner/angket, observasi, wawancara, atau gabungan ketiganya. (Hidayat, 2008)

Metode penelitian yang dipakai dalam penelitian ini adalah metode eksperimen. Eksperimen adalah cara pengumpulan data yang dilakukan oleh peneliti dengan cara manipulasi atau melakukan pengubahan pada variabel bebas (independen variabel) untuk mengetahui dampak atau akibatnya pada variabel terikat atau dependent. (Suyanto 2011)

Dalam melakukan analisis, data terlebih dahulu harus diolah dengan tujuan mengubah data menjadi informasi. Dalam statistik, informasi yang diperoleh dipergunakan untuk proses pengambilan keputusan, terutama dalam pengujian hipotesis. (Hidayat, 2009)Langkah-langkah analisa data pada penelitian ini adalah dengan editing, koding dan tabulating.

Analisa data dalam penelitian ini menggunakan analisa Bivariat. Analisa bivariat digunakan untuk mengetahui keterkaitan dari 2 (dua) atau lebih variabel. Hasil ini digunakan untuk menjawab tujuan umum yang tertuang pada hipotesis penelitian. Adapun langkah-langkah analisa bivariat adalah sebagai berikut :

1) Menulis hipotesis alternatif

Hipotesis pada penelitian ini adalah : ada pengaruh pemberian fisioterapi dada terhadap kebersihan jalan napas pada pasien ISPA di Desa Pucung Eromoko Wonogiri.

2) Membuat tabel statistik

3) Menentukan tingkat Kepercayaan 
Tingkat kepercayaaan untuk penelitian ini adalah $\mathrm{p}=0,05$ atau $5 \%$ : tingkat kepercayaan $5 \%$ yang berarti kemungkinan terjadi 5 kesalahan kesimpulan dari 100 kesimpulan yang dibuat.

4) Menentukan uji statistik

a) Manual

Peneliti memasukkan hasil penelitian dengan menggunakan Paired $t$ Test, yaitu untuk menguji efektivitas suatu perlakuan terhadap suatu besaran variabel yang ingin ditentukan. Metode ini menggambarkan bahwa responden diperiksa sebelum diberi fisioterapi dada (hasil pre test) selanjutnya diperiksa kebersihan jalan napasnya setelah fisioterapi dada (hasil post test) dan masing-masing responden dibandingkan antara sebelum dan sesudah fisioterapi dada.

b) Komputer

Menggunakan paired t test dengan bantuan SPSS for windows seri 18

c) Kriteria penarikan kesimpulan

Untuk menjawab hipotesa diterima atau ditolak, peneliti menggunakan pedoman sebagai berikut :

(1) Manual Jika $t$ hitung $>t$ tabel maka hipotesa diterima Jika $t$ hitung $<\mathrm{t}$ tabel maka hipotesa ditolak

(2) Komputer / SPSS Jika $\alpha<0,05$ maka hipotesa diterima. Jika $\alpha>0,05$ maka hipotesa ditolak.

\section{HASIL PENELITIAN}

Jumlah responden dalam penelitian ini sebanyak 26 orang karena hanya ditemukan 26 orang yang menderita ISPA.
Desa Pucung terletak di Kabupaten Wonogiri, di sini mayoritas penduduk bekerja sebagai petani. Salah satunya adalah petani tembakau. Dari hasil pertanian tembakau tersebut setiap panen biasanya dibawa kerumah. Banyak anak-anak di desa ini yang sering mengalami ISPA dan biasanya penatalaksanaan yang di berikan selama ini hanya dengan membelikan obat yang telah diresepkan dokter atau hanya langsung membeli obat di apotek, mereka belum mengetahui tentang fisioterapi dada yang juga mempunyai kegunaan untuk membersihkan jalan napas.

Selama penelitian, peneliti banyak menemukan hambatan, faktor penghambat yang dirasakan peneliti selama proses penelitian diantaranya dalam proses ini peneliti harus memberi penyuluhan terlebih dahulu karena banyak responden yang kurang mengerti tentang ISPA dan penatalaksanaannya yang salah satunya adalah fisioterapi dada. Tetapi akhirnya proses penelitian dapat berjalan lancar karena didukung oleh beberapa hal diantaranya sebagian besar responden kooperatif sehingga penelitian ini dapat terselesaikan dengan baik.

Dari hasil penelitian yang telah dilakukan maka diperoleh hasil sebagai berikut:

Tabel 4.3. Distribusi Frekuensi Kebersihan Jalan Napas Sebelum Diberikan Fisioterapi Dada Pada Pasien ISPA

\begin{tabular}{|c|l|c|c|}
\hline No & $\begin{array}{l}\text { Kebersihan } \\
\text { jalan napas }\end{array}$ & Frekuensi & $\%$ \\
\hline 1 & Bersih & 3 & 11,53 \\
\hline 2 & Tidak bersih & 23 & 88,47 \\
\hline & Jumlah & 26 & 100 \\
\hline
\end{tabular}

Dari tabel di atas diperoleh informasi bahwa persentase pada kategori 
kebersihan jalan napas sebelum diberikan fisioterapi dada, responden yang jalan napasnya tidak bersih $(88,47 \%)$ sebanyak 23 responden, sedangkan yang jalan napasnya bersih $(11,53 \%)$ sebanyak 3 responden.

Tabel 4.4. Distribusi Frekuensi Kebersihan Jalan Napas Sesudah Diberikan Fisioterapi Pada Pasien ISPA

\begin{tabular}{|c|l|c|c|}
\hline No & $\begin{array}{c}\text { Kebersihan } \\
\text { jalan napas }\end{array}$ & Frekuensi & $\%$ \\
\hline 1 & Bersih & 18 & 69,23 \\
\hline 2 & Tidak bersih & 8 & 30,70 \\
\hline & Jumlah & 26 & 100 \\
\hline
\end{tabular}

Dari tabel di atas diperoleh informasi bahwa persentase pada kategori kebersihan jalan napas sesudah diberikan fisioterapi dada pada pasien ISPA, sebanyak 18 responden $(69,23 \%)$ untuk kategori jalan napas bersih, sedangkan sebanyak 8 responden $(30,70 \%)$ untuk kategori jalan napas tidak bersih.

Hasil penelitian

Tabel 4.5. Hasil Uji SPSS

\begin{tabular}{|c|c|c|c|}
\hline $\begin{array}{c}\text { Paired } \\
\text { sample t test }\end{array}$ & $\mathrm{N}$ & $\mathrm{t}$ & $\begin{array}{c}\text { Sig. } \\
(2- \\
\text { tailed) }\end{array}$ \\
\hline $\begin{array}{c}\text { Kebersihan } \\
\text { jalan napas } \\
\text { pre dan post } \\
\text { fisioterapi } \\
\text { dada }\end{array}$ & 26 & -5.839 &, 000 \\
\hline
\end{tabular}

Dari hasil uji Paired t-test program SPSS versi 18 menunjukkan hasil $t$ hitung sebesar -5.839 dengan $P$ value $\quad 0.000<0.05$. Artinya kebersihan jalan napas sebelum fisioterapi dada berbeda dengan sesudah fisioterapi dada. Nilai negatif pada $t$ hitung menunjukkan nilai awal lebih rendah dari nilai berikutnya. Ho ditolak dan $\mathrm{Ha}$ diterima sehingga ada pengaruh pemberian fisioterapi dada terhadap kebersihan jalan napas pada pasien ISPA di Desa Pucung Eromoko Wonogiri.

\section{PEMBAHASAN}

Dari hasil penelitian pengaruh pemberian fisioterapi dada terhadap kebersihan jalan napas pada pasien ISPA di Desa Pucung Eromoko Wonogiri diperoleh hasil uji dengan Paired t-test program SPSS versi 18 dengan $t$ hitung sebesar -5.839 dengan $P$ value $0,000<0,05$, yang berarti Ho ditolak dan Ha diterima, sehingga dapat ditarik kesimpulan bahwa ada pengaruh pemberian fisioterapi dada terhadap kebersihan jalan napas pada pasien ISPA di Desa Pucung Eromoko Wonogiri.

Fisioterapi dada merupakan kelompok terapi yang digunakan dengan kombinasi untuk memobilisasi sekresi pulmonar. Terapi ini terdiri dari drainage postural, perkusi dada, dan vibrasi. Fisioterapi dada harus diikuti dengan batuk produktif dan pengisapan pada klien yang mengalami penurunan kemampuan untuk batuk. (Potter dan Perry, 2006)

Menurut Muttaqin (2008), fisioterapi dada termasuk didalamnya adalah drainage postural (postural drainage), perkusi dan vibrasi dada, latihan pernapasan, dan batuk efektif. Tujuan fisioterapi dada adalah membuang sekresi bronkhial, memperbaiki efisiensi otot-otot pernapasan.

Dari penelitian yang telah dilakukan yaitu dengan memberikan fisioterapi pada pasien ISPA didapatkan hasil rata-rata kebersihan jalan napas sebagian besar bersih. Klien yang memproduksi sekret berlebih dapat mengurangi sekretnya setelah dilakukan fisioterapi dada, klien juga 
merasa pernapasannya menjadi lancar.

Kebersihan jalan napas adalah suatu kondisi dimana individu mampu untuk batuk secara efektif, dan tidak ada penumpukan sekret. (Muttaqin, 2008)

Kriteria kebersihan jalan napas menurut Muttaqin (2008), antara lain:

a. Bunyi napas terdengar bersih

b. Ronkhi tidak terdengar

c. Menunjukkan batuk efektif

d. Tidak ada penumpukan sekret di saluran napas

e. Pernapasan klien normal (16-20 $\mathrm{x} /$ menit) tanpa penggunaan otot bantu napas

Dalam penelitian yang dilakukan didapatkan hasil kebersihan jalan napas sebelum diberikan fisioterapi dada, responden yang jalan napasnya tidak bersih sebanyak 23 responden $(88,47 \%)$, sedangkan untuk kategori bersih sebanyak 3 responden (11,53\%). Kemudian sesudah diberikan fisioterapi dada, responden untuk kategori jalan napas bersih sebanyak 18 responden $(69,23 \%)$, sedangkan jumlah responden untuk kategori jalan napas tidak bersih adalah 8 responden $(30,70 \%)$.

Menurut Potter dan Perry (2006), pedoman untuk fisioterapi dada antara lain:

a. Ketahui tanda-tanda vital klien

b. Obat-obatan yang dipakai klien yang dapat menurunkan toleransi klien terhadap perubahan posisi postural drainage

c. Riwayat medis klien

d. Tingkat fungsi kognitif klien

e. Toleransi klien akan latihan fisik

Dari hasil penelitian ditemukan 8 responden setelah dilakukan fisioterapi dada jalan napas tetap tidak bersih. Hal ini disebabkan karena ada anak yang kurang kooperatif dan fisiknya kurang sehat sehingga pada saat diberikan fisioterapi dada anak merasa lemas, kemungkinan penyebab lain dikarenakan pemberian fisioterapi dada hanya diberikan sebanyak dua kali sehingga hasilnya kurang maksimal. Selain itu partisipasi anak dalam teknik batuk efektif tidak terkontrol karena klien tidak mengikuti instruksi dengan benar.

Pada saat melakukan penelitian didapatkan hasil sebelum dilakukan fisioterapi dada kebersihan jalan napas klien sebagian besar tidak bersih dan banyak memproduksi sekret. Banyak klien yang tidak dapat mengeluarkan sekretnya secara sendiri sehingga mengganggu pernapasan klien. Kemudian setelah dilakukan fisioterapi dada sebagian besar klien mampu mengeluarkan sekretnya.

Dari hasil penelitian pengaruh pemberian fisioterapi dada terhadap kebersihan jalan napas pada pasien ISPA di Desa Pucung Eromoko Wonogiri diperoleh hasil uji dengan Paired t-test program SPSS versi 18 dengan $t$ hitung sebesar -5.839 dengan $P$ value $0,000<0,05$, yang berarti Ho ditolak dan Ha diterima, sehingga dapat ditarik kesimpulan bahwa ada pengaruh pemberian fisioterapi dada terhadap kebersihan jalan napas pada pasien ISPA di Desa Pucung Eromoko Wonogiri.

Menurut Potter dan Perry (2006), fisioterapi dada merupakan kelompok terapi yang digunakan dengan kombinasi untuk memobilisasi sekresi pulmonar. Terapi ini terdiri dari drainage postural, perkusi dada, dan vibrasi. Sedangkan menurut Muttaqin (2008), tujuan fisioterapi dada adalah membuang sekresi bronkhial, memperbaiki efisiensi otot-otot pernapasan. 
Kebersihan jalan napas adalah suatu kondisi dimana individu mampu untuk batuk secara efektif, dan tidak ada penumpukan sekret. (Muttaqin, 2008)

Penatalaksanaan kebersihan jalan napas menurut Somantri (2009), antara lain:

a. Humidifikasi, misalnya nebulizer

b. Fisioterapi dada

c. Obat bronkodilator

d. Inhalasi mekanik

Fisioterapi dada merupakan salah satu penatalaksanaan kebersihan jalan napas, sehingga dari hasil penelitian ini dapat disimpulkan dari beberapa macam penatalaksanaan yang bisa dilakukan untuk kebersihan jalan napas termasuk didalamnya adalah fisioterapi dada. Dari hasil penelitian pemberian fisioterapi dada berpengaruh terhadap kebersihan jalan napas.

\section{KESIMPULAN}

Dari hasil penelitian yang dilakukan pada anak-anak yang terkena ISPA mengenai pengaruh pemberian fisioterapi dada terhadap kebersihan jalan napas pada pasien ISPA di Desa Pucung Eromoko Wonogiri didapatkan hasil $t$ hitung sebesar 5.839 sehingga nilai $P$ value 0,000 $<0,05$, yang berarti Ho ditolak dan $\mathrm{Ha}$ diterima, sehingga dapat ditarik kesimpulan bahwa ada pengaruh pemberian fisioterapi dada terhadap kebersihan jalan napas pada pasien ISPA di Desa Pucung Eromoko Wonogiri.

\section{SARAN}

1. Bagi Penderita ISPA di Desa Pucung

Khususnya bagi orang tua penderita ISPA Desa Pucung sebaiknya mencegah kejadian ISPA dengan melakukan fisioterapi dada dalam penatalaksanaannya untuk membersihkan jalan napas.

2. Bagi Masyarakat Desa Pucung
Bagi masyarakat desa Pucung sebaiknya melakukan fisioterapi dada dalam penatalaksanaan ISPA untuk kebersihkan jalan napas.

3. Bagi Institusi Kesehatan

Bagi institusi kesehatan sebaiknya melakukan tindakan yang dapat mengurangi kejadian ISPA dengan pendidikan kesehatan tentang fisioterapi dada pada masyarakat.

4. Bagi Institusi Pendidikan

Bagi institusi pendidikan hasil penelitian ini diharapkan dapat digunakan untuk pengembangan pengetahuan bagi peserta didik di lingkungan keperawatan terutama pada penatalaksanaan ISPA.

\section{DAFTAR PUSTAKA}

Hartono dan Dwi Rahmawati. Gangguan Pernapasan pada Anak: ISPAPanduan bagi Tenaga Kerja dan Umum.Yogyakarta : Nuha Medika, 2012.

Herdman, T. Heather ed. Diagnosa Keperawatan : Definisi dan Klasifikasi 2012-2014. Jakarta : EGC, 2012.

Hidayat, A. Aziz Alimul. Metode Penelitian Keperawatan dan Teknik Analisis Data. Jakarta : Salemba Medika, 2008.

Riset Keperawatan dan Teknik Penulisan IImiah. Jakarta: Salemba Medika, 2008.

Kusyati, Eni. Keterampilan dan Prosedur Laboratorium Keperawatan Dasar. Jakarta : EGC, 2006. 
Muttaqin, Arif. Asuhan Keperawatan Klien dengan Gangguan Sistem Pernapasan. Jakarta: Salemba Medika, 2008.

Asuhan Keperawatan Klien dengan Gangguan Sistem Persarafan. Jakarta: Salemba Medika, 2008.

Potter, Patricia A dan Anne G. Perry. Fundamental Keperawatan. Edisi 4. Alih Bahasa : Renata Kumalasari, et al. Jakarta : EGC, 2006.

Rahajoe, Nastiti, Bambang Supriyanto, dan Darmawan Budi Setyanto. Respirologi Anak. Edisi I. Jakarta: Badan Penerbit IDAI, 2008.

Riwidikdo, Handoko. Statistik Kesehatan Belajar Mudah Teknik Analisis Data Dalam Penelitian Kesehatan. Yogyakarta : Mitra Cendikia Press, 2007.
Somantri, Irman. Asuhan Keperawatan pada Klien dengan Gangguan Sistem Pernapasan. Edisi II. Jakarta: Salemba Medika, 2009.

Suyanto.Metodologi dan Aplikasi Penelitian Keperawatan. Yogyakarta : Nuha Medika, 2011.

Yasmin, Niluh Gede dan Christantie Effendy.Keperawatan

Medikal Bedah Klien dengan Gangguan Sistem Pernapasan. Jakarta: EGC, 2004.

Widjaja, Anton. Penanganan ISPA pada Anak di Rumah Sakit Kecil Negara Berkembang Pedoman untuk Dokter dan Petugas Kesehatan Senior. Jakarta: EGC, 2003.

\footnotetext{
1 Dosen AKPER Panti Kosala Surakarta

2 Dosen AKPER Panti Kosala Surakarta

3 Mahasiswa AKPER Panti Kosala Surakarta
} 